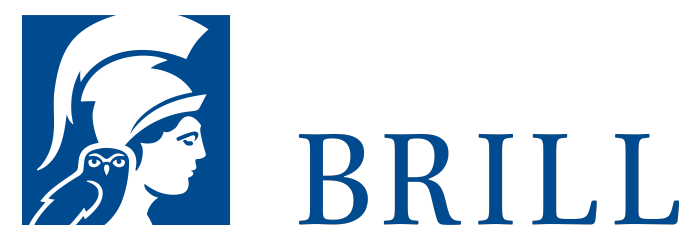

\title{
Luthers Reformation und ihre interkonfessionellen Auswirkungen auf Kirchenmusik und Musikkultur im 16. Jahrhundert
}

Author: Klaus Wolfgang Niemöller

Die Reformation zeitigte auf dem Gebiet der Kirchenmusik weitreichende Folgen, die weit über den Einfluss der 36 deutschen Lutherlieder hinausgehen. Die Weitertradierung kunstvoller lateinischer Kirchenmusik durch die lutherischen Lateinschulen entspricht der Musikanschauung der Reformatoren. Die differente interkonfessionelle Praxis in den evangelischen und katholischen Territorien wird besonders am Beispiel bikonfessioneller Reichsstädte wie Augsburg und Regensburg verdeutlicht.

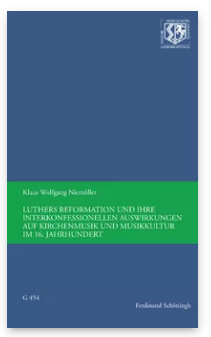

Pages: 51 Seiten Language:

German

Subjects:

General, Theology and World

Christianity

Publisher: Brill | Schöningh

Series:

Nordrhein-

Westfälische

Akademie der

Wissenschaften und der Künste - Vorträge: Geisteswissenschaften, Volume: 454

E-Book (PDF)

Released online: 11 Nov 2019

ISBN: 978-3657-72847-3

List price

Paperback

Publication date: 2o Apr 2018

ISBN: 978-3506-72847-O List price 
For more information see brill.com

Order information: Order online at brill.com +44330 333 0049 | customerservices@brill.com Submission information: brill.com/authors

Titles published by Brill | Fink, Brill | mentis or Brill | Schöningh: +49(o)715413279216| brill@brocom.de 